\title{
Greenhouse gas emissions and energy consumption in asphalt plants
}

\author{
Emissões de gases de efeito estufa e consumo de energia em usinas de \\ asfalto
}

\author{
Maicon Basso dos Santos' \\ Jefferson Candido" \\ Sofia de Souza Bauléll' \\ Yuri Melo Müller de Oliveiralv \\ Liseane Padilha Thives ${ }^{\mathrm{V}}$
}

\begin{abstract}
Hot-mix asphalt used in pavement layers is produced by asphalt plants. In Brazil, despite the fact that these industrial units produce greenhouse gases, no control or measurement protocol has yet been established. This study aims to quantify emissions in different asphalt plants, in terms of carbon dioxide equivalent $\left(\mathrm{CO}_{2 \text { eq }}\right)$ and energy consumption. Asphalt plants were selected according to their type (batch or drum mix); production capacity (80 to $340 \mathrm{t} / \mathrm{h}$ ), and whether mobile or fixed. In each plant, emissions were quantified and the energy consumption spent on drying and heating aggregates in the dryer drum was evaluated. The fuels used in the drier drum such as low pour point (LPP) oil, liquefied petroleum gas (LPG), and natural gas (NG) were evaluated and compared. The methodology consisted of surveying the thermal power of the dryer drum specified on the suppliers' catalog to calculate the volume of fuel required per ton of asphalt mixture produced. Based on the criterion of the lower calorific value of each fuel, the volume of fuel used was calculated according to the production of the asphalt plants. Through the GHC protocol tool, the quantification of emissions of carbon dioxide $\left(\mathrm{CO}_{2}\right)$, methane $\left(\mathrm{CH}_{4}\right)$, and nitrous oxide $\left(\mathrm{N}_{2} \mathrm{O}\right)$ gases was obtained, and then transformed into $\mathrm{CO}_{2 \text { eq }}$ emissions. As a result, lower energy consumption was observed in the mobile batch plants and higher consumption in the mobile counterflow drum mix plants. On average, $27.69 \%$ less energy per ton of processed aggregate was needed compared to the mobile counterflow plants. The use of natural gas in the dryer drum and for all plant models was the least emissive fuel. The results showed that for the mobile batch type with a capacity of $140 \mathrm{t} / \mathrm{h}$, the emission was $13.62 \mathrm{~kg}$ of $\mathrm{CO}_{2 \mathrm{eq}} / \mathrm{t}$. On the other hand, with the mobile counterflow type with a capacity of $200 \mathrm{t} / \mathrm{h}, 13.64 \mathrm{~kg}$ of $\mathrm{CO}_{2 \text { eq }} / \mathrm{t}$ was produced. Finally, with the fixed counterflow type with a production capacity of $240 \mathrm{t} / \mathrm{h}$ and $300 \mathrm{t} / \mathrm{h}$, emissions of $13.67 \mathrm{~kg}$ of $\mathrm{CO}_{2 \text { eq }} / \mathrm{t}$ were obtained. Through this study, the mobile batch plant with a capacity of $140 \mathrm{t} / \mathrm{h}$ using natural gas showed the least environmental impact. When natural gas was used, this model obtained energy consumption and emissions $54.5 \%$ lower than the mobile counterflow model with a capacity of $50 \mathrm{t} / \mathrm{h}$ which showed the worst environmental performance.
\end{abstract}

Keywords: Global warming; Fuel; Paving. 


\section{Resumo}

As misturas asfálticas a quente usadas em camadas de revestimento são produzidas em usinas de asfalto. Apesar dessas unidades industriais serem emissoras de gases de efeito estufa, no Brasil ainda não foi estabelecido controle ou protocolo de medições. Este estudo tem como objetivo quantificar as emissões em diferentes usinas de asfalto, em termos de dióxido de carbono equivalente $\left(\mathrm{CO}_{2 e q}\right)$ e consumo de energia. As usinas de asfalto foram selecionadas em função do tipo, batelada (gravimétrica ou batch) e volumétrica (drum-mixer); da capacidade de produção (80 a 340 t/h) e se estacionária ou fixa. Em cada usina foram quantificadas as emissões e avaliado o consumo de energia despendido para secagem e aquecimento de agregados no tambor secador. Os seguintes combustíveis utilizados no tambor secador óleo de baixo ponto de fluidez (BPF), gás liquefeito do petróleo (GLP) e gás natural (GN) foram avaliados e comparados. A metodologia consistiu no levantamento da potência térmica do tambor secador a partir do catálogo dos fornecedores para calcular o volume de combustível necessário por tonelada de mistura asfáltica produzida. Tendo como critério o poder calorífico inferior de cada combustível, foi calculado o volume de combustível gasto em função da produção das usinas de asfalto. Através da ferramenta GHC protocol foi realizada a quantificação das emissões dos gases dióxido de carbono $\left(\mathrm{CO}_{2}\right)$, metano $\left(\mathrm{CH}_{4}\right)$ e óxido nitroso $\left(\mathrm{N}_{2} \mathrm{O}\right)$ e, então, transformadas em emissões de $\mathrm{CO}_{2 \text { eq. }}$. Como resultado, observou-se o menor consumo de energia nas usinas tipo usina batelada móvel e maior consumo nas usinas volumétricas de contrafluxo móvel. Em média, as usinas tipo batelada móvel necessitaram 27,69\% menos energia por tonelada de agregado processado em relação à de contrafluxo móvel. O uso de gás natural no tambor secador e para todos os modelos de usinas, foi o combustível menos emissivo. Os resultados mostraram que para o tipo batelada móvel e capacidade de $140 \mathrm{t} / \mathrm{h}$, a emissão foi de $13,62 \mathrm{~kg}$ de $\mathrm{CO}_{2 \text { eq }} / \mathrm{t}$, no caso do tipo contrafluxo móvel e capacidade de $200 \mathrm{t} / \mathrm{h}$, obteve $13,64 \mathrm{~kg}$ de $\mathrm{CO}_{2 \text { eq }} / \mathrm{t}$ e o tipo contrafluxo fixa e capacidades de produção de $240 \mathrm{t} / \mathrm{h}$ e $300 \mathrm{t} / \mathrm{h}$, emissões de $13,67 \mathrm{~kg}$ de $\mathrm{CO}_{2 \text { eq }} / \mathrm{t}$. Por meio deste estudo, a usina batelada móvel e capacidade de $140 \mathrm{t} / \mathrm{h}$ com uso de gás natural obteve menor impacto ambiental. Esse modelo obteve consumo de energia e emissões, quando utilizado gás natural $54,5 \%$ menor que o modelo contrafluxo móvel com capacidade de $50 \mathrm{t} / \mathrm{h}$ que apresentou o pior desempenho ambiental.

Palavras-Chave: Aquecimento Global; Combustível; Pavimentação.

\section{Introduction}

Asphalt plants are industrial units that produce hot-mix asphalt used in layers of flexible pavements. The production of asphalt mixtures occurs after dosing in the laboratory, in which the proportions are established in relation to the type and quantity of aggregates and asphalt content. The production process in the asphalt plant consists of providing, in relation to the dosage, the aggregates in the cold silos, subsequent heating and drying in the dryer drum, and mixing with the heated and injected asphalt which occurs in a mixer.

There are two basic types of asphalt plants: batch or drum mix plants. Drum mix plants can also be of parallel flow, if the flame of the dryer drum is in the same direction 
as the entrance of the aggregates, or of counterflow, in the opposite direction. The plants vary in terms of production capacity (t/h), and can also be fixed (stationary) or mobile (INDOT, 2016). As with any industrial unit, asphalt plants generates greenhouse gases.

High fuel consumption during the production process leads to the release of polluting gases, especially carbon dioxide $\left(\mathrm{CO}_{2}\right)$, carbon monoxide $(\mathrm{CO})$, nitrous oxides $(\mathrm{NO})$, and sulfur dioxide $\left(\mathrm{SO}_{2}\right)$, which are harmful to the environment, the people directly involved in the production process, and for those who live in the surrounding areas (USEPA, 2004; NAPA, 2014).

The main source of emissions in an asphalt plant is the dryer drum and these emissions are strongly caused by the fuel used in the process. The most commonly emitted gases are carbon dioxide $\left(\mathrm{CO}_{2}\right)$, carbon monoxide (CO), nitrous oxides ( $\mathrm{NO}$ ), and sulfur dioxide $\left(\mathrm{SO}_{2}\right)$. Another emission source is the asphalt binder heating tank. In these tanks, the main emissions are total organic carbons (TOCs), volatile organic compounds (VOCs), and polycyclic aromatic hydrocarbons (PAHs) (BERNUCCI et al., 2008; RUBIO et al., 2013; ZANETTI et al., 2016; MERIGHI and SUZUKI, 2017).

In recent years, there has been a greater interest for the preservation of the environment and issues related to the conservation of natural resources in several areas. In the case of the road infrastructure area, alternatives have been researched regarding environmental control in the production of asphalt mixtures, especially in terms of reducing mixing temperatures, decreasing the use of fossil fuels in the production process, and reusing stone aggregates for recycling. The consumption of energy resources as well as emissions of greenhouse gases are important parameters regarding the implementation of sustainable methods (MILLET et al., 2007; HUANG et al., 2009). Rubio et al. (2013) highlight the contribution of the road sector to emissions of air pollutants due to the use of a large volume of virgin aggregates, in addition to the high consumption of energy.

From 2008 to 2014, an average of 2.64 million tons per year of asphalt material was consumed at Petrobras plants. In fact, the average has decreased to 1.94 million 
tonnes since 2015. From 2015 to 2018, an average of 2 million tons were consumed. Moreover, 1.69 million tons was consumed in 2019 (ABEDA, 2020).

The road modal is predominant in Brazil, with $61 \%$ of cargo and $95 \%$ of passengers being transported by road. The Brazilian road network has 1.7 million kilometers, but only 213,453 kilometers are paved, which represents only $12.4 \%$ (CNT, 2019). In this sense, considering that the paved extension is small, the potential for using asphalt mixtures has a high growth potential. However, the boost production of asphalt mixtures would result in increased emissions, which must be measured and controlled.

The greenhouse effect has been studied mainly due to the uncontrolled process of warming the planet and its effects will be felt in this century and in the next. With the warming induced by human activities, the natural variation of the climate overlaps and the temperature rise is not uniform and smooth in different places on the planet or over time. In addition, the duration of cold weeks is decreasing as observed since the 1980s in the USA. As a result of global warming, changes in precipitation patterns are observed with a higher incidence of heat waves and droughts, greater intensity of hurricanes, and rising sea levels from 1 feet $(30.48 \mathrm{~cm})$ to 8 feet $(243.84 \mathrm{~cm})$ by 2100 (NASA, 2020a).

The amount of greenhouse gases released into the environment at an asphalt plant can come from the production phase, the transportation of materials from the source to processing, and use in the field (MUENCH, 2010; WANG et al., 2012). The amount of emissions differs in the two types of processes analyzed (continuous or discontinuous), but they can be estimated with less uncertainty due to emission factors (USEPA, 2004).

In Brazil, air quality standards are established by the National Environment Council (CONAMA), Resolution No. 491 (BRASIL, 2018). Resolution No. 491 defines air quality standards as a management tool and establishes limits for the concentration of pollutants in relation to the time of exposure, so as not to compromise the 
environment and the health of the population. However, there is still no control or protocol for measuring emissions in Brazilian asphalt plants.

In the process of mixing asphalt mixtures, different fuels can be used. In France, there are asphalt plants operated with natural gas (VENTURA et al., 2009). In Spain, heavy fuel oil is used (RUBIO et al., 2013). In China, coal is used as a fuel (PENG et al., 2015). In Brazil, the plants are designed for the use of several types of fuels such as LPP oil, diesel oil, natural gas, LPG, and shale oil (AMMANN, 2020; CIBER, 2020; MARINI, 2020).

This study aims to quantify emissions in different asphalt plants, in terms of carbon dioxide equivalent $\left(\mathrm{CO}_{2 e q}\right)$ and energy consumption. Emissions from different fuels used in the dryer drum in various types of plants were evaluated and quantified. Finally, the amount of energy required for processing per ton of aggregate was also measured.

\subsection{Greenhouse gases}

The greenhouse effect is a natural process that allows life on Earth. A portion of the solar energy is reflected directly into space the moment it hits the atmosphere of the Earth and the other part goes beyond it, being absorbed by the oceans and the surface of the planet, leading to its heating; or reflected by the planet surface and being retained by the presence of greenhouse gases. The proper balance between the solar energy that affects the atmosphere of the Earth and the energy reflected in the form of heat keeps climatic balance (BRASIL, 2020a).

However, when the natural balance is disrupted, due to the excessive emission of certain gases, it results in the warming of the planet. Global warming leads to climate changes such as rising temperatures and uncontrolled hydrological systems, resulting in more severe cases to the process of desertification in productive areas. Other climatic problems arising are the occurrence of storms, hurricanes, and tornadoes, as well as the melting of the polar ice caps leading to increased volume of water in the oceans and loss of fauna and flora in different parts of the planet (BRASIL, 2020b). 
The main greenhouse gases are carbon dioxide $\left(\mathrm{CO}_{2}\right)$, methane $\left(\mathrm{CH}_{4}\right)$, nitrous oxide $\left(\mathrm{N}_{2} \mathrm{O}\right)$, sulfur hexafluorethane $\left(\mathrm{SF}_{6}\right)$, hydrofluorocarbons $(\mathrm{HFCs})$, and perfluorocarbons (PFCs). The Global Warming Potential is a relative measure that compares a given greenhouse gas with the same amount of carbon dioxide (whose potential is defined as 1), being called equivalent carbon dioxide $\left(\mathrm{CO}_{2 \text { eq }}\right)$ (FUNDAÇÃO GETÚLIO VARGAS, 2008).

Emission sources are physical units or processes that release some greenhouse gas into the atmosphere, the main ones being related to deforestation, transport, enteric fermentation, fossil fuel thermoelectric plants, and industrial processes. Carbon dioxide equivalent $\left(\mathrm{CO}_{2 \mathrm{eq}}\right)$ has been the measure used to compare the emissions of various greenhouse gases, which is based on the Global Warming Potential (GWP). This parameter represents the amount of energy that a ton of gas will absorb over a period of 100 years in relation to a ton of $\mathrm{CO}_{2}$. Thus, the greater the potential, the greater is the heating power on the planet (USEPA, 2020).

Water vapor is the most abundant greenhouse gas in the atmosphere. It is suspended in the troposphere and increases due to the warming of the planet. The increase in water vapor concentration leads to the incidence of clouds and precipitation, becoming one of the main feedback mechanisms for the greenhouse effect (NASA, 2020b). Table 1 shows the main greenhouse gases, their Global Warming Potential, and emission source. 
Table 1 - Greenhouse gases

\begin{tabular}{|c|c|c|c|}
\hline Gas & Emission source & GWP(1) & Description \\
\hline Carbon Dioxide $\left(\mathrm{CO}_{2}\right)$ & $\begin{array}{l}\text { Combustion of fossil } \\
\text { fuels and soil use } \\
\text { change. }\end{array}$ & 1 & $\begin{array}{l}\text { Used as a reference for the } \\
\text { GWP classification of } \\
\text { greenhouse gases. }\end{array}$ \\
\hline Methane $\left(\mathrm{CH}_{4}\right)$ & $\begin{array}{l}\text { Produced by the } \\
\text { decomposition of } \\
\text { organic matter. }\end{array}$ & 21 & $\begin{array}{c}\text { Found in landfills, dumps, } \\
\text { hydroelectric power plants, } \\
\text { cattle breeding, and rice } \\
\text { cultivation. }\end{array}$ \\
\hline Nitrous oxide $\left(\mathrm{N}_{2} \mathrm{O}\right)$ & $\begin{array}{l}\text { Treatment of animal } \\
\text { waste, burning of fossil } \\
\text { fuels, use of fertilizers, } \\
\text { and industrial processes. }\end{array}$ & 310 & $\begin{array}{l}\text { It remains on average } 100 \\
\text { years in the atmosphere. }\end{array}$ \\
\hline Fluorinated Gases & $\begin{array}{l}\text { Released from industrial } \\
\text { processes. }\end{array}$ & $\begin{array}{c}\text { High } \\
\text { contribution } \\
\text { value }\end{array}$ & ${ }^{(2)} \mathrm{SF}_{6}, \mathrm{HFCs}$, e PFCs \\
\hline
\end{tabular}

GWP(1) - Global Warming Potential; (2) Sulfur hexafluoride $\left(\mathrm{SF}_{6}\right)=23,900$, Hydrofluorocarbons $(\mathrm{HFCs})=$ ranges from 140 to 11,700 , and Perfluorocarbons (PFCs) = ranges from 6,500 to 9,200.

Source: Adapted from BRASIL, 2020a; BRASIL, 2020b.

\subsection{Asphalt Plants}

The production process in asphalt plants involves heating the aggregates through the dryer drum and the asphalt binder using heated tanks. The heating temperature of the materials (aggregates and binder) must not be less than $107^{\circ} \mathrm{C}$ and more than $177^{\circ} \mathrm{C}$ for the asphalt binder and the aggregate is heated from $10^{\circ} \mathrm{C}$ to $15^{\circ} \mathrm{C}$ above the temperature used in the binder (BERNUCCI et al., 2008).

The main source of emissions in a plant is the dryer drum. In order to dry and heat the aggregates at high temperatures, it requires the use of fuels. There are two main types of asphalt plants: batch plant and counter flow or parallel flow drum mix plant (Figure 1). 
Figure 1 - Types of asphalt plants and their components

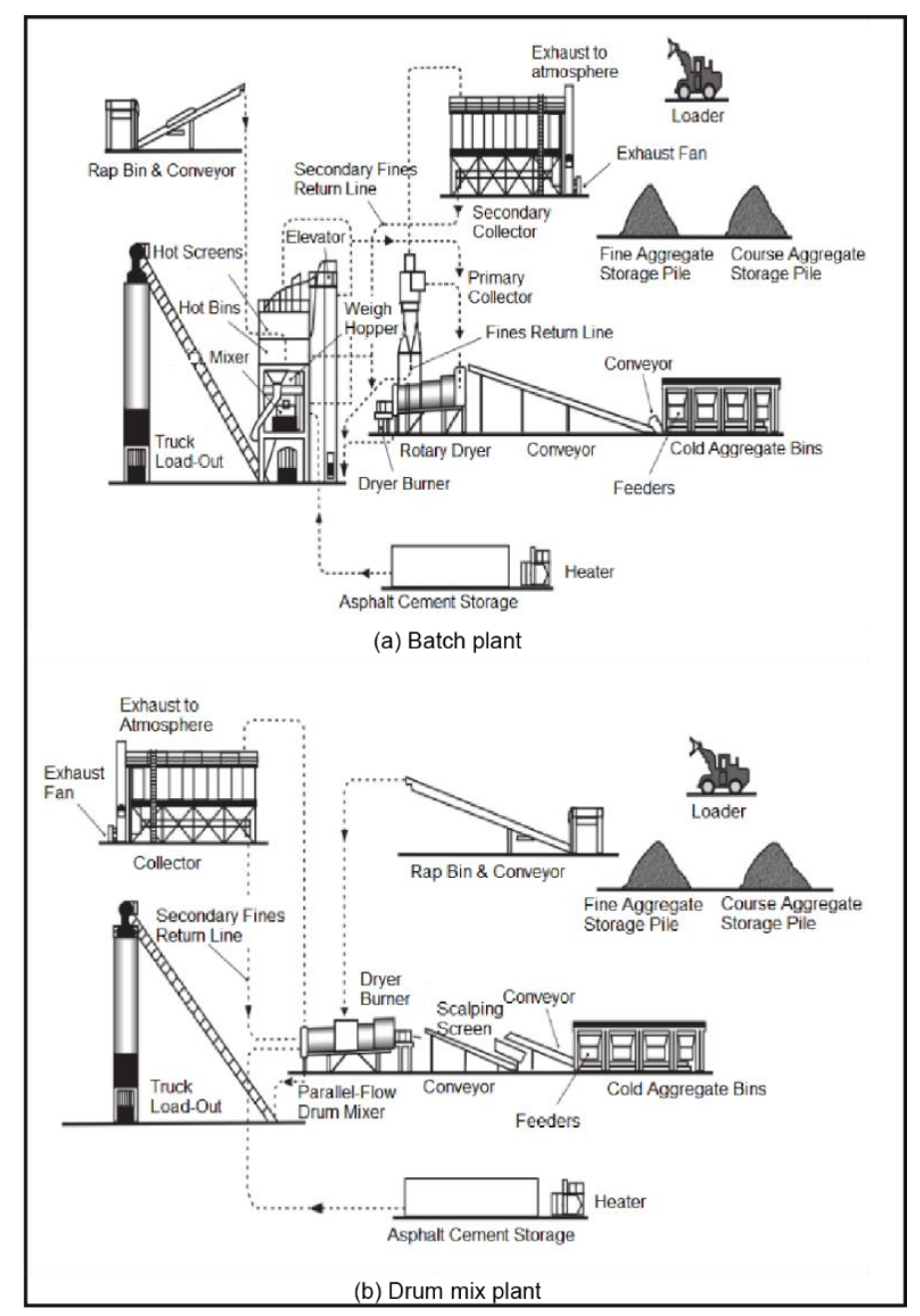

Source: Adapted from USEPA, 2004.

Regarding the batch asphalt plant (Figure 1a), the different aggregates of the cold silos, previously calibrated, are transported by means of conveyor belts to the dryer drum. In the drum, after drying and heating, they are transported through a (hot) elevator, being sieved and stored in hot silos. Electronically, the operator controls the weighing and quantity of aggregates entering the mixer into which the asphalt binder is introduced and mixing proceeds. At each cycle, portions of the mixture are unloaded on trucks and transported to the field (USEPA, 2004). In these plants, the mixing process takes place in batches, through a repeated process to meet the volume required for daily production. Peterson (2018) highlights the advantages of this type of plant such as: greater flexibility in production and higher quality in the final product since the aggregates are sieved and weighed with each batch. 
Drum mix plants (Figure 1b) have the production of asphalt mixture continuously. In this scenario, in addition to heating the aggregates, mixing is also carried out in the dryer drum itself. Depending on the direction of entry of the aggregates in relation to the flame position of the dryer drum, drum mix plants are classified as counterflow (the aggregate and the flame are in opposite directions) or parallel (the aggregate and the flame are positioned in the same direction). Peterson (2018) considers this type of asphalt plant as an advantage since the mixing and drying process does not suffer interruption due to the continuous flow of asphalt and aggregate in the dryer drum, generating a homogeneous mixture. Thus, the main difference in processing in drum mix and batch plants is that the dryer drum in continuous plants also functions as a mixer (USEPA, 2004).

Asphalt plants have two main categories of emissions: ducted or fugitive sources. Ducted sources are those in which the emission occurs through a duct or confined space and those from fugitive sources are those in which the emission occurs directly to the environment. The largest source of ducted emissions in plants occurs in the dryer drum, with emissions consisting of water vapor, particulate matter, and combustion products $\left(\mathrm{CO}_{2}, \mathrm{NOx}, \mathrm{CO}, \mathrm{CH}_{4}\right.$, and volatile organic compounds). Counterflow plants can result in less emission of organic compounds when compared to parallel flow plants, as the mixture of aggregate, asphalt binder, and RAP (reclaimed asphalt pavement) occurs in an area that is not in contact with hot air (USEPA, 2004 ).

Peinado et al. (2011) highlight that the moisture content of the aggregates is directly related to the performance in terms of the production capacity of an asphalt plant. The higher the moisture content, the longer the drying and heating time and, consequently, the production time and emissions are high. Protection with the cover of the aggregate stacks is always recommended.

Fuel oils are widely used in industries to produce heat in furnaces, boilers, and internal combustion engines. These oils are classified according to their viscosity, sulfur content, and pour point. LPP oil is part of this group of oils extracted from petroleum (PETROBRAS, 2019a). LPP is a fuel that consists of a mixture of hydrocarbon molecules 
containing three to four carbon atoms, which although found in the gaseous state under normal conditions of temperature and pressure, can be liquefied by compression or cooling (PETROBRAS, 2019b).

Natural gas is composed of hydrocarbons that remain in a gaseous state under normal atmospheric conditions. It is essentially composed of methane $\left(\mathrm{CH}_{4}\right)$ with levels greater than $70 \%$, ethane $\left(\mathrm{C}_{2} \mathrm{H}_{6}\right)$ in smaller proportions, and propane $\left(\mathrm{C}_{3} \mathrm{H}_{8}\right)$ normally in levels below 2\% (ANP, 2020). Xu and Lin (2019) evaluated the impact of the use of natural gas in reducing $\mathrm{CO}_{2}$ emissions and observed that the use of this fuel provided a reduction in emissions when compared to other fossil fuels.

\section{Material and Methods}

The adopted methodology consists of four phases described below; whose flowchart is shown in Figure 2.

Figure 2 - Flowchart and methodology phases

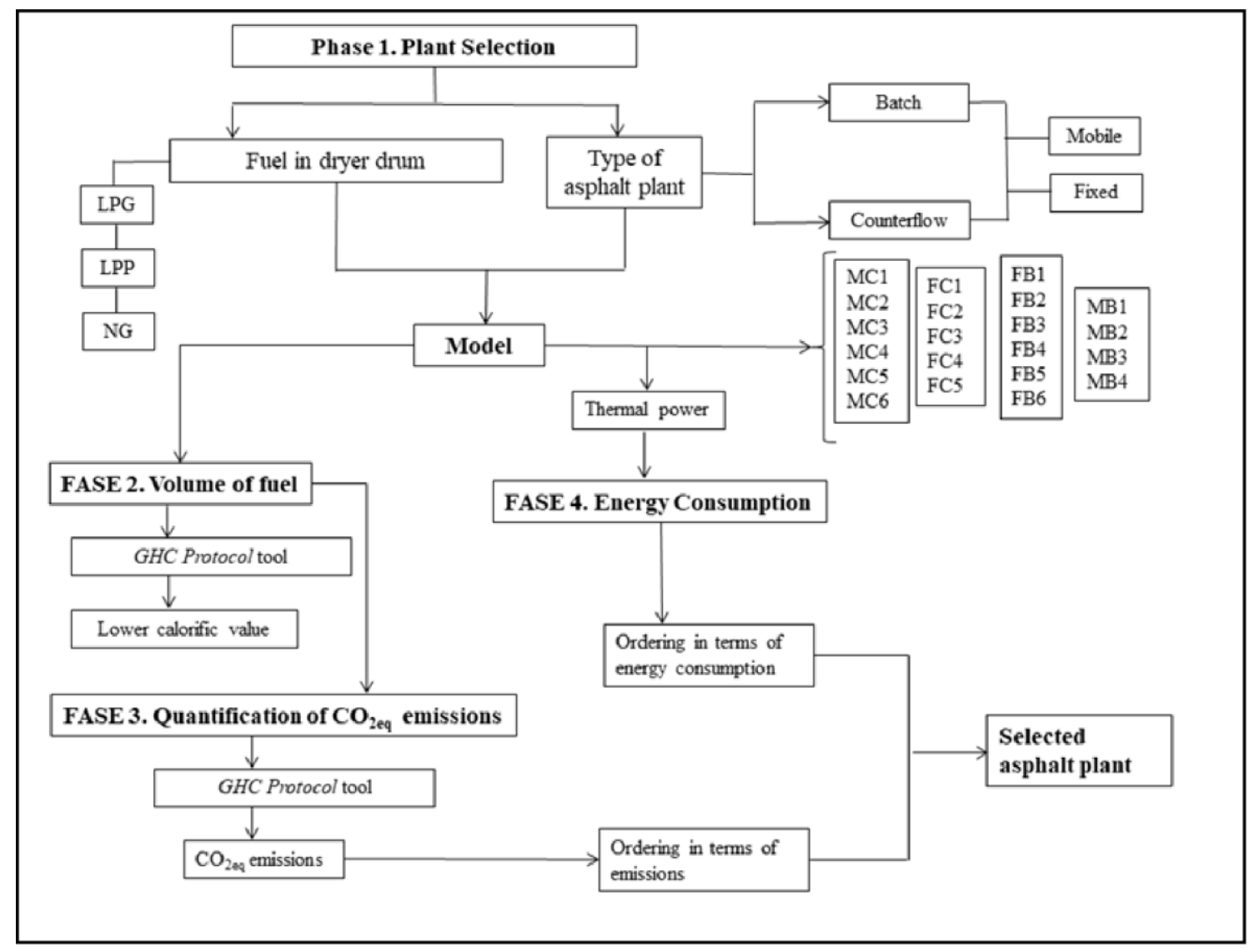


- Phase 1 - Plant selection - two types of plants were selected: batch and counterflow drum mix plants, fixed and mobile, resulting in four plant models. By consulting the manufacturing companies and depending on the production capacity of each plant, the thermal power required for the dryer drum was obtained. For each model, the use of the following fuels in the dryer drum was considered: low pour point oil, liquefied petroleum gas, and natural gas. Thus, through the combination of plant types and fuels, a factorial of twenty-one models was evaluated, whose characteristics are shown in Table 2.

- Phase 2 - Fuel volume for each model - in this phase, the quantification of the volume of fuel necessary to meet the thermal power of each model of dryer drum of the plants was made. The volume calculation for each fuel was performed using the lower calorific value data contained in the GHC protocol tool (Table 3)

- Phase 3 - Quantification of CO2eq emissions - the GHC protocol tool allows, through the calculation of stationary combustion, the determination of emissions of greenhouse gases (Table 3) and transformation in terms of $\mathrm{CO}_{2 \text { eq. }}$. For each model of asphalt plant, the emission of $\mathrm{CO}_{2 \text { eq }}$ per ton of mixture produced was evaluated. In this way, it was possible to order emissions by model and select the least emissive model.

- Phase 4 - Energy consumption - in this phase, the survey of the energy required for drying and heating per ton of aggregate was carried out. With the thermal power data established in Phase 1, the necessary energy was calculated by dividing the thermal power of the dryer drum (kcal / h) by the production capacity of the plant ( $\mathrm{t}$ / h). Thus, it was possible to determine the model that obtained the lowest and highest energy consumption for the production of one ton of asphalt mix. 
Table 2 - Characterization of the plants

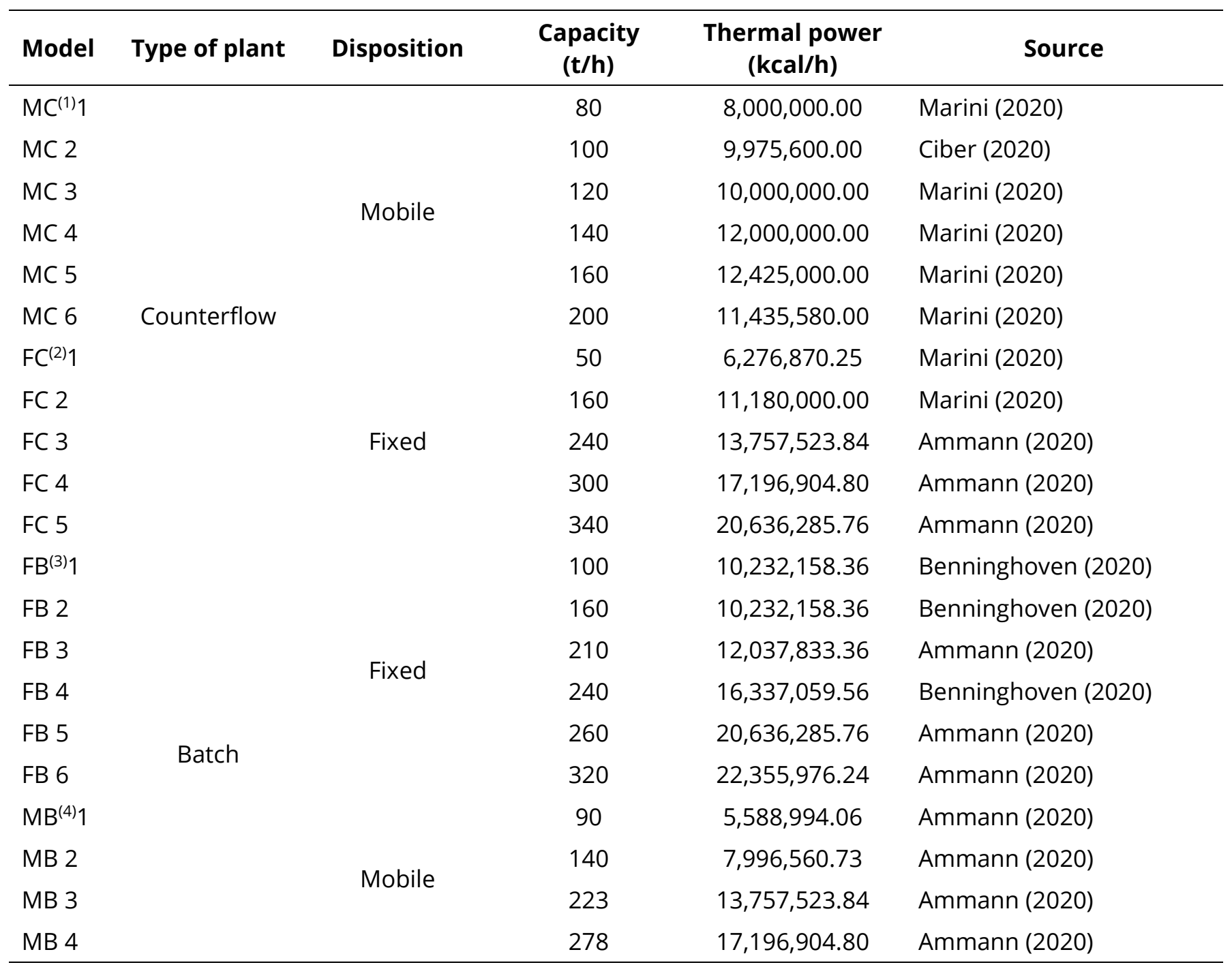

(1) $\mathrm{MC}=$ Mobile counterflow; ${ }^{(2)} \mathrm{FC}=$ Fixed counterflow; (3) FB = Fixed Batch; and (4) MB = Mobile Batch.

Table 3 - Calculation parameters obtained from the GHC Protocol tool

\begin{tabular}{lccc}
\hline \multicolumn{1}{c}{ Fuel } & Lower calorific value (GJ/t) & Gases & Emission Factors (kg/un) \\
\hline \multirow{2}{*}{ LPG (t) } & \multirow{3}{*}{46.5} & $\mathrm{CO}_{2}$ & 2,931 \\
& & $\mathrm{CH}_{4}$ & 0.04647 \\
& \multirow{3}{*}{49.8} & $\mathrm{~N}_{2} \mathrm{O}$ & 0.004647 \\
\multirow{2}{*}{ Natural gas $\left(\mathrm{m}^{3}\right)$} & & $\mathrm{CO}_{2}$ & 2.1 \\
& & $\mathrm{CH}_{4}$ & 0.00004 \\
& & $\mathrm{~N}_{2} \mathrm{O}$ & 0.000004 \\
LPP oil (l) & 40.2 & $\mathrm{CO}_{2}$ & 3.1 \\
& & $\mathrm{CH}_{4}$ & 0.00012 \\
& & $\mathrm{~N}_{2} \mathrm{O}$ & 0.000024 \\
\hline
\end{tabular}




\section{Results and Discussion}

\subsection{Emissions}

Figure 3 shows the comparison of emissions in terms of $\mathrm{CO}_{2 \text { eq }}$ for mobile counterflow plants. It was observed that the fossil fuel LPP oil (low pour point) was the most emissive, followed by LPG (liquefied petroleum gas) and NG (natural gas). Regarding ordering, it was found that the MC6 model (greater capacity) and the use of natural gas fuel had lower emissions than the others for each ton.

On average, for all models, with the use of natural gas (NG) fuel, there was a reduction in $\mathrm{CO}_{2 \text { eq }}$ emissions of $9.59 \%$ in relation to LPG and $26.09 \%$ in relation to LPP oil. The study by Bueche and Dumont (2012) showed that the use of fuel oil emitted $38 \%$ more $\mathrm{CO}_{2 \text { eq }}$ when compared to natural gas.

Paranhos and Petter (2013) concluded that plants with natural gas emitted half of $\mathrm{CO}_{2}$, nine times less $\mathrm{NO}_{x}$, and eighteen times less $\mathrm{CO}$ than plants that use heavy fuel oil. The results of the two studies are similar to that found in that the use of natural gas in the dryer drum was less emissive and showed better environmental performance in relation to LPP oil. With the use of natural gas, the least emissive model (MC6) emits $42.80 \%$ less $\mathrm{CO}_{2 \text { eq }}$ per ton, when compared to the model with the highest emission (MC1).

Figure 3 - $\mathrm{CO}_{2 \text { eq }}$ emissions in models of a mobile counterflow (MC) asphalt plant

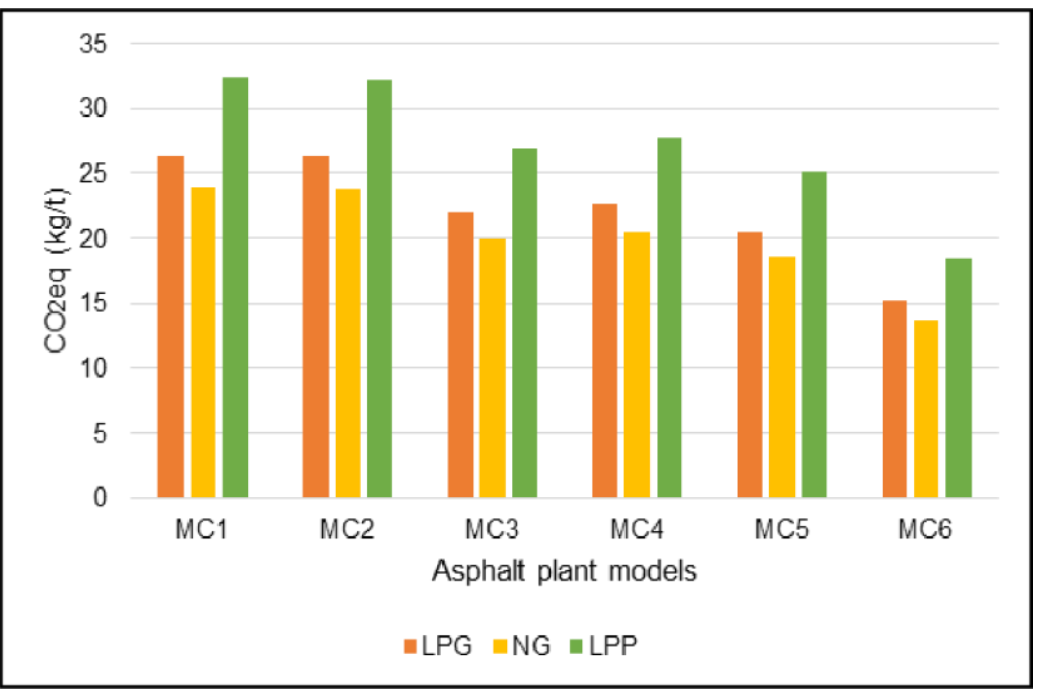


Emissions in terms of $\mathrm{CO}_{2 e q}$ for the fixed counterflow type models (Figure 4) showed that the LPP oil fuel was the most emissive, as well as in the mobile counterflow plants. In addition, the FC3 and FC4 models, when using natural gas, had the lowest emissions in relation to the others. Also, the FC1 model (lowest capacity) presented the highest emissions per processed ton. Using natural gas, the least emissive models (FC3 and $\mathrm{FC} 4$ ) emit $54.35 \%$ less $\mathrm{CO}_{2 \text { eq }}$ per ton, when compared to the highest emissive model (FC1).

In the study by White et al. (2010) when using heavy fuel oil, an emission of 66.3 $\mathrm{kg} / \mathrm{t}$ of $\mathrm{CO}_{2 \text { eq }}$ was observed, higher than the values verified in this study (all models resulted in emissions below $32.26 \mathrm{~kg} / \mathrm{t}$ of $\mathrm{CO}_{2 e q}$ ). Almeida-Costa e Benta (2016) found a reduction of $30 \%$ in relation to $\mathrm{CO}_{2}$ emissions with the use of natural gas in relation to other fuels (diesel oil and fuel oil). The results of the studies showed that the burning of natural gas in the dryer drum results in lower emissions compared to other fossil fuels.

Figure 5 shows the results obtained for the fixed batch type models. In this case, it was observed that the use of LPP oil also led to increased emissions. The most emissive model was the FB1. $\mathrm{CO}_{2 \text { eq }}$ emissions were reduced by $18.25 \%$ and $26.11 \%$ when burning LPG and natural gas, respectively, instead of LPP oil. The combustion of natural gas to replace LPG leads to an average reduction of $9.62 \%$ in $\mathrm{CO}_{2 \text { eq }}$ emissions. When using natural gas, the least emissive model (FB3) emits $38.09 \%$ less $\mathrm{CO}_{2 \text { eq }}$ per ton, when compared to the model with highest emission (FB1).

Figure $4-\mathrm{CO}_{2 \text { eq }}$ emissions in fixed counterflow (FC) asphalt plant models

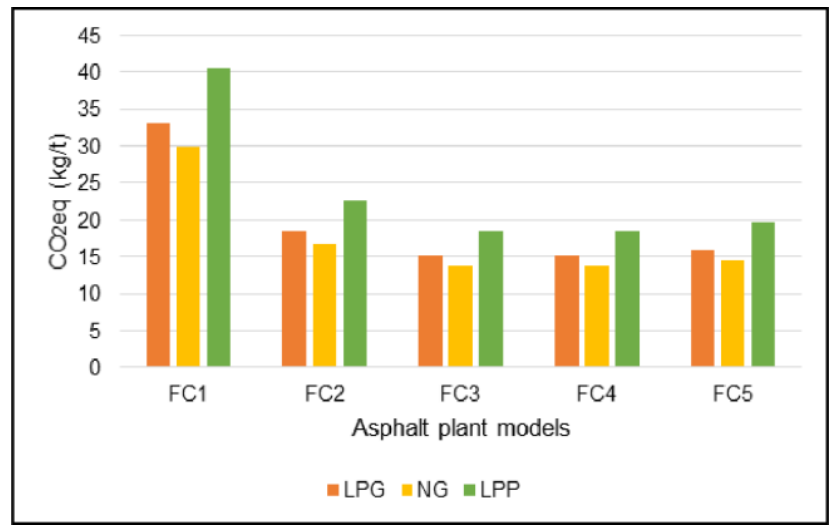


Figure $5-\mathrm{CO}_{2 e q}$ emissions in fixed batch (FB) asphalt plant models

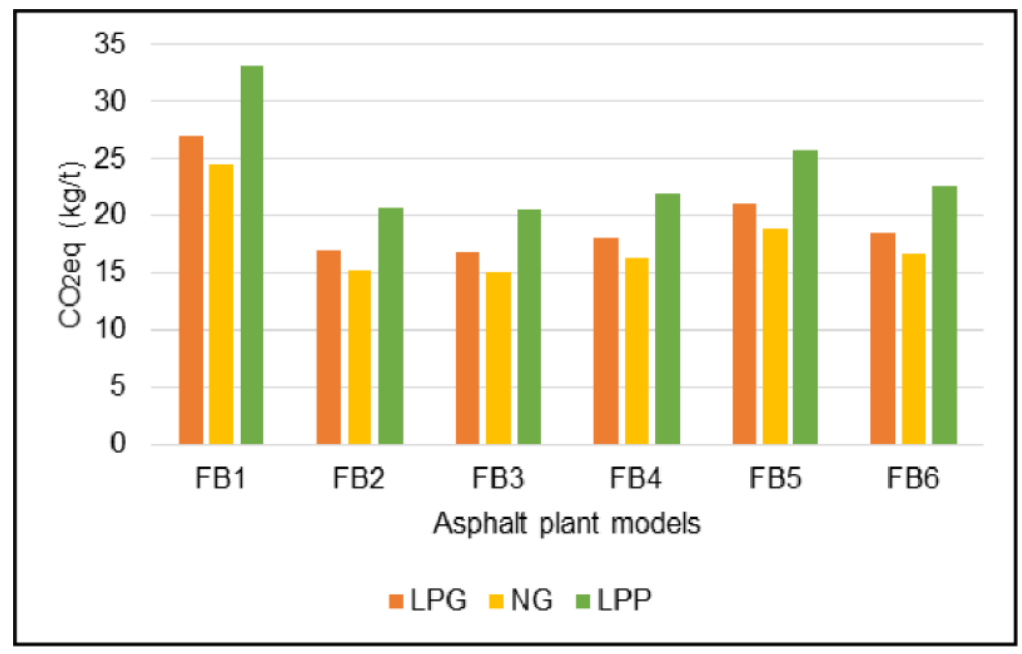

Regarding the mobile batch models (Figure 6), the lowest emissions were observed in the MB2 model, whereas the highest emissions are associated with the MB1 model. When natural gas was used, the MB2 model (less emissive) emits 8.03\% less $\mathrm{CO}_{2 \text { eq }}$ per ton of aggregate processed when compared to the MB1 model (more emissive).

Figure $6-\mathrm{CO}_{2 \text { eq }}$ emissions in mobile batch (MB) asphalt plant models

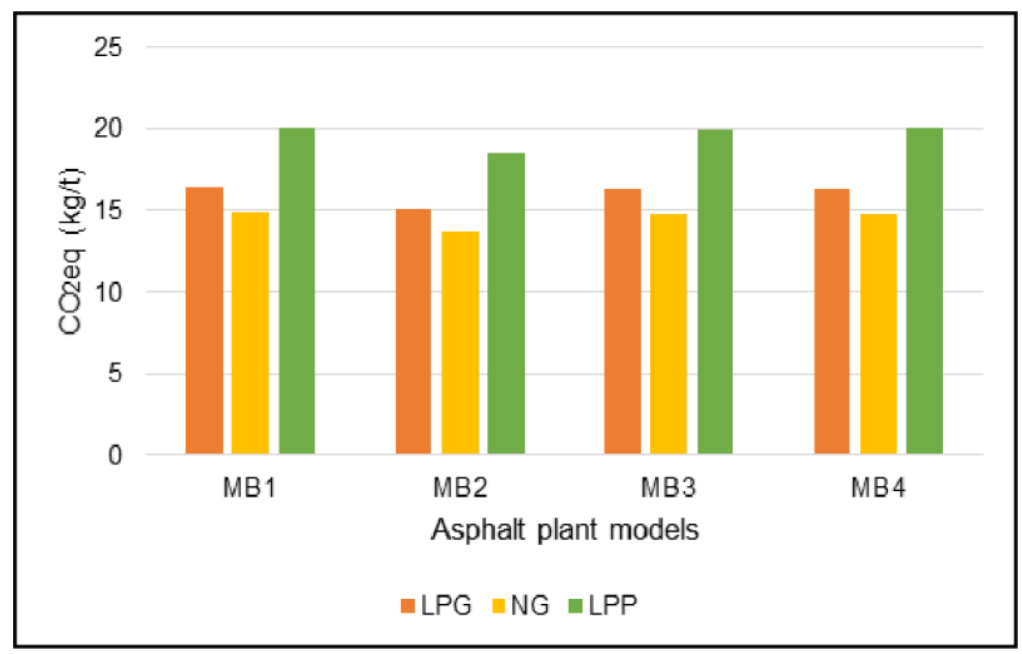

\subsection{Energy consumption}

The results presented are related to the energy consumption required per ton of aggregate processed in the dryer drum. It was verified in the catalog of suppliers 
that the moisture content considered for the aggregates was 3\% in most of the models analyzed. However, in fixed batch models the content varied from $4 \%$ to $5 \%$.

Figure 7 shows the energy consumption of the mobile counterflow plants, in which it can be seen that the MC6 model (greater capacity) required the lowest demand $(57,178 \mathrm{kcal} / \mathrm{t})$. Thus, regarding models, the greater the capacity of the plant, the lower is the energy consumption. The aggregate processing in the lowest consumption model, MC6 $(57,178 \mathrm{kcal} / \mathrm{t})$, requires $42.82 \%$ less energy per ton, when compared to the highest consumption model, MC1 $(100,000 \mathrm{kcal} / \mathrm{t})$. The energy consumption of all plant models had a higher demand than reported in the study by Peinado et al. (2011) who observed the expenditure of $63.1 \mathrm{kWh}(54,292.54 \mathrm{kcal} / \mathrm{t})$ of energy per ton of asphalt mixture. The energy consumption in the burner of a medium-sized plant is approximately 70 -100 kWh $(60,189.7$ - 85,984.52 kcal) per ton (EAPA, 2007).

The results of the fixed counterflow plants in Figure 8 show that the lowest energy demand for heating and drying the aggregate was observed in the FC3 and FC4 models $(57,323 \mathrm{kcal} / \mathrm{t})$, and the highest demand in the FC1 model $(125,537 \mathrm{kcal} / \mathrm{t})$. Thus, the aggregate processing in the FC4 model requires $54.34 \%$ less energy per ton processed when compared to the FC1 model.

Figure 7 - Energy consumption in mobile counterflow (MC) asphalt plant models

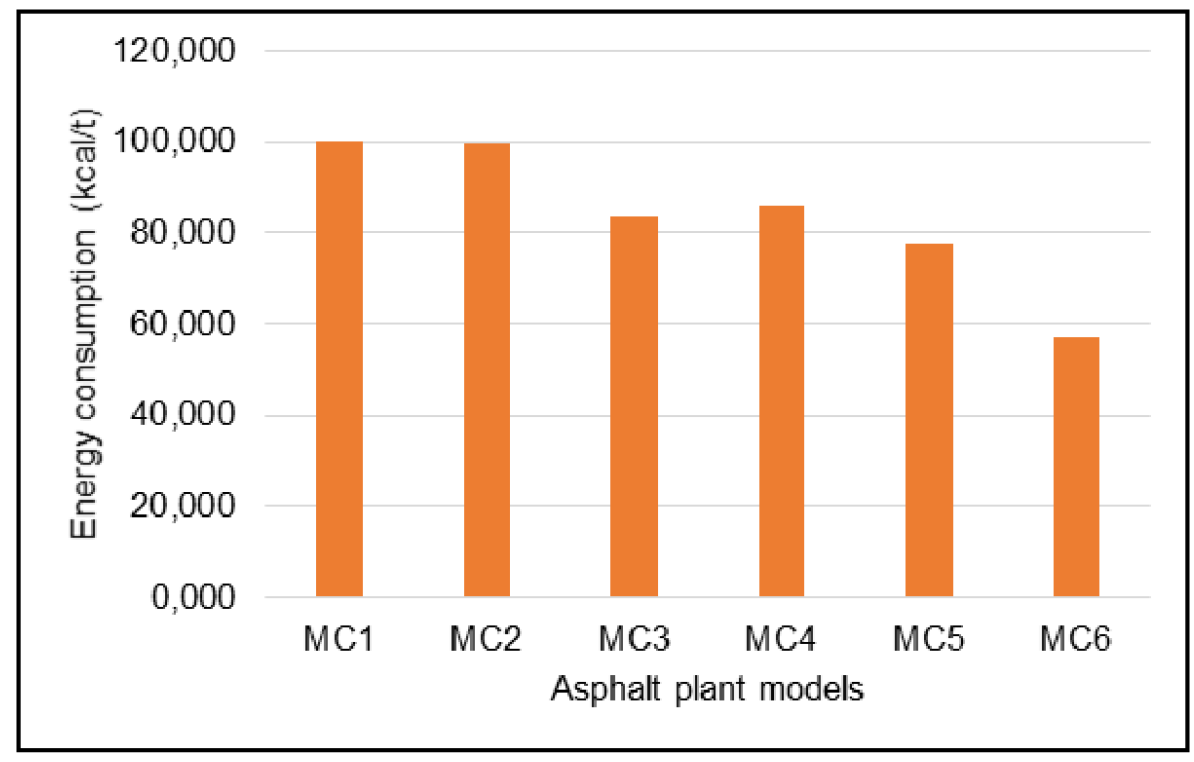


Figure 8 - Energy consumption in fixed counterflow (FC) asphalt plant models

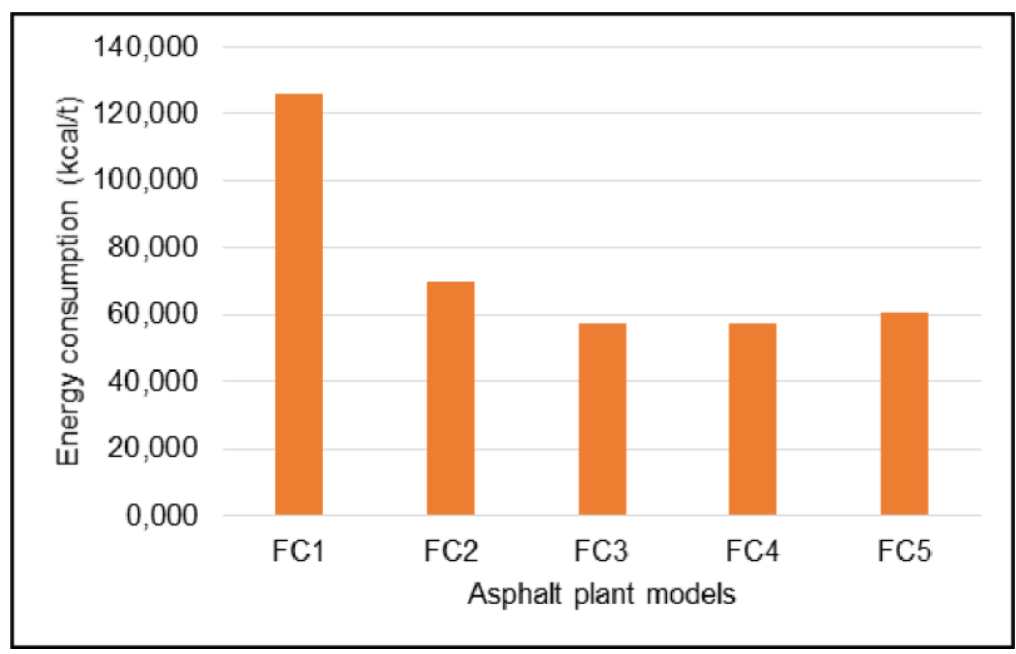

Figure 9 shows the results of the fixed batch plants. It was observed that the lowest demand occurred in the FB3 plant model (63,357 kcal). In contrast, the FB1 plant model $(102,322 \mathrm{kcal} / \mathrm{t})$ demanded more energy for this process. Thus, the use of the FB3 model requires 38\% less energy per ton processed, when compared to the FB1 model.

The FB1 and FB5 models had higher energy consumption than that observed by Androjić et al. (2020) in the field being 82kWh (70,507.31 kcal). In general, hot-mixer asphalt plants spend around 300,000 BTUs (75,598.73 kcal) to dry and heat the aggregate to one ton of hot-mix asphalt (HMA) aggregate (KRISTJÁNSDÓTTIR et al., 2007).

The results obtained for the mobile batch plants are shown in Figure 10. The lowest energy consumption is associated with the MB2 model $(57,118.29 \mathrm{kcal} / \mathrm{t})$ and, in contrast, the highest energy consumption occurred in the MB1 model $(62,099,93$ $\mathrm{kcal} / \mathrm{t}$ ). Thus, the aggregate processing in the MB2 model requires $8.02 \%$ less energy when compared to the MB1 model. 
Figure 9 - Energy consumption in fixed batch (FB) asphalt plant models

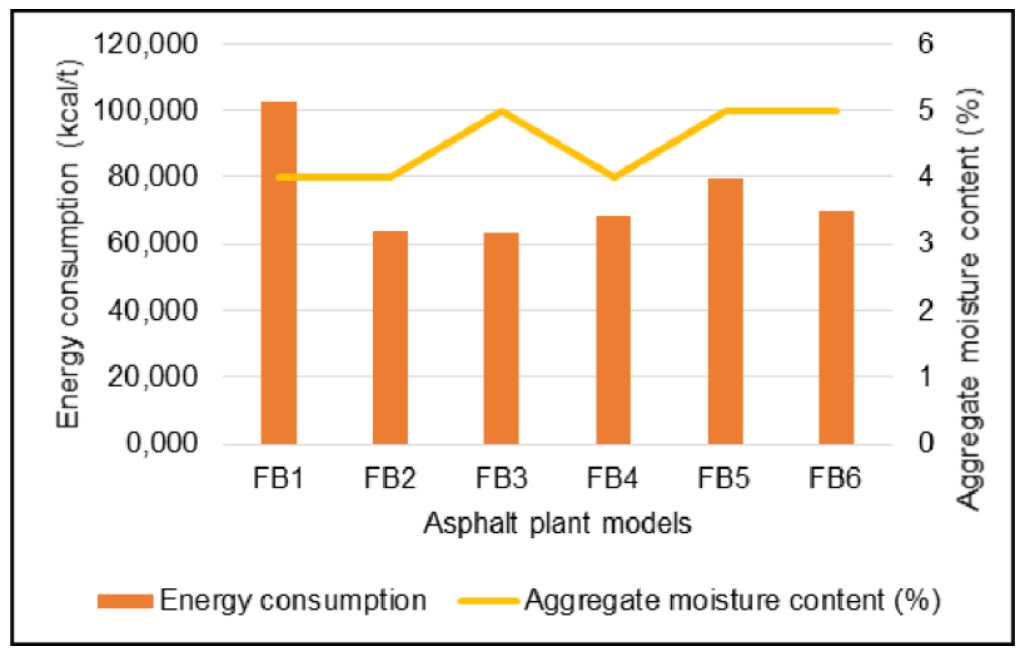

Figure 10 - Energy consumption in mobile batch (MB) asphalt plant models

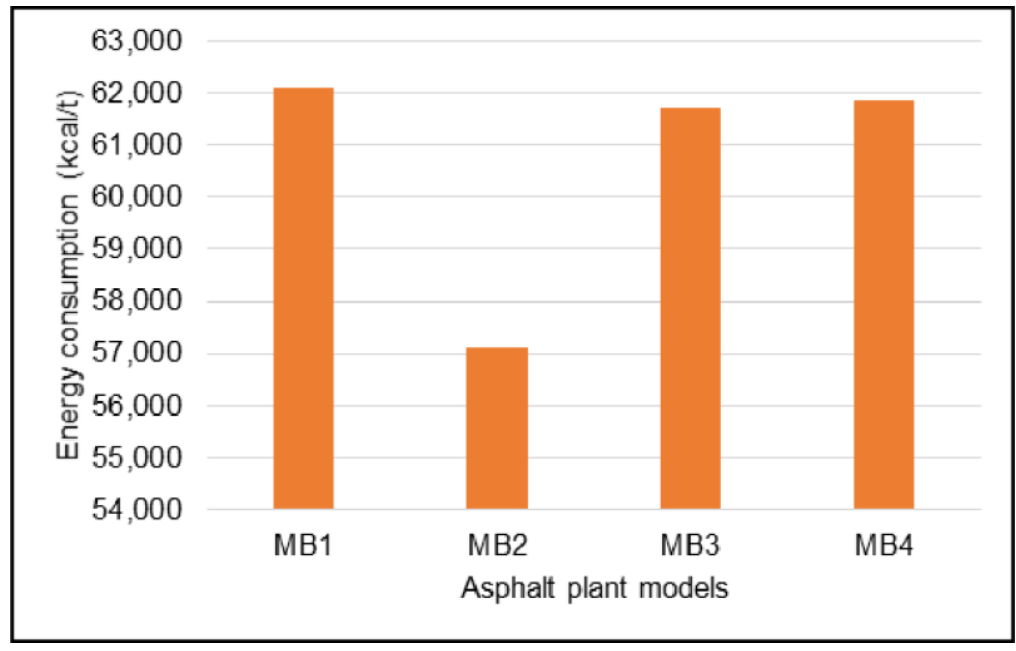

\subsection{Sorting between different plant models}

Figure 11 shows the average emissions for each type of plant. It was observed that on average the mobile counterflow type, using LPP oil is the most emissive. In contrast, mobile batch plants have, on average, the best environmental performance when compared to the others, when natural gas is used. Mobile batch plants emit $27.5 \%$ less $\mathrm{CO}_{2 e q}$ per ton of aggregate processed when compared to mobile counterflow plants.

Figure 12 shows the mean consumption per ton of aggregate processed in each type of plant considered in this study, in order to analyze the type of plant that requires 
less energy. It was observed that the mobile counterflow plants require a greater amount of energy per ton of dry and heated aggregate. In contrast, mobile batch plants, on average, demand less energy per ton of processed aggregate.

On average, mobile batch models use $27.69 \%$ less energy per ton of aggregate than mobile counterflow models. The average energy consumption in the dryer of the fixed batch plants was higher than that observed by Bueche and Dumont (2012), who reported the consumption of $182 \mathrm{MJ} / \mathrm{t}(43,499 \mathrm{kcal} / \mathrm{t})$ for drying and heating the aggregates. Ventura et al. (2009) observed a consumption of $182.57 \mathrm{MJ} / \mathrm{t}(43,469.95$ $\mathrm{kcal} / \mathrm{t}$ ) which is lower than that observed in this study. Peurifoy et al. (2015) highlight that counterflow plants can have up to $12 \%$ higher productivity, thus justifying the results observed for fixed counterflow plants, which demanded greater energy consumption when compared to the other models.

Figure 11 - Comparison between all models analyzed in this study

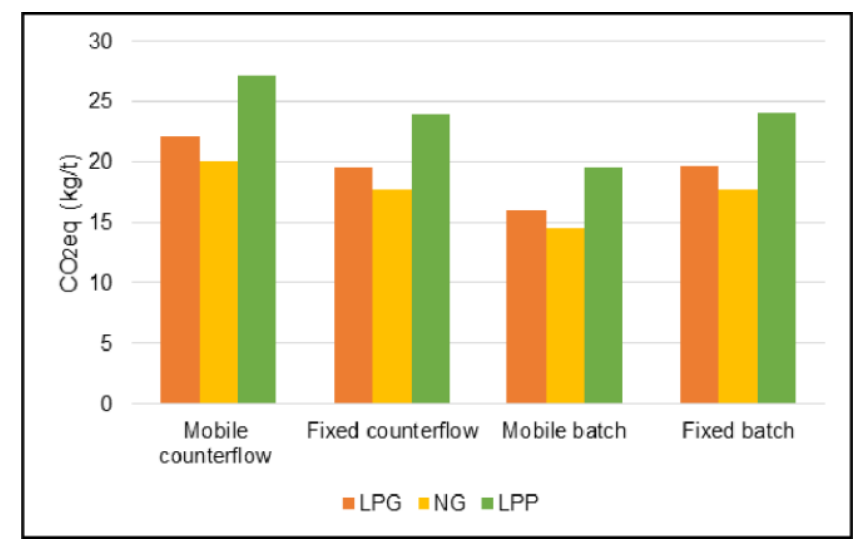

Figure 12 - Comparison between all models analyzed in this study

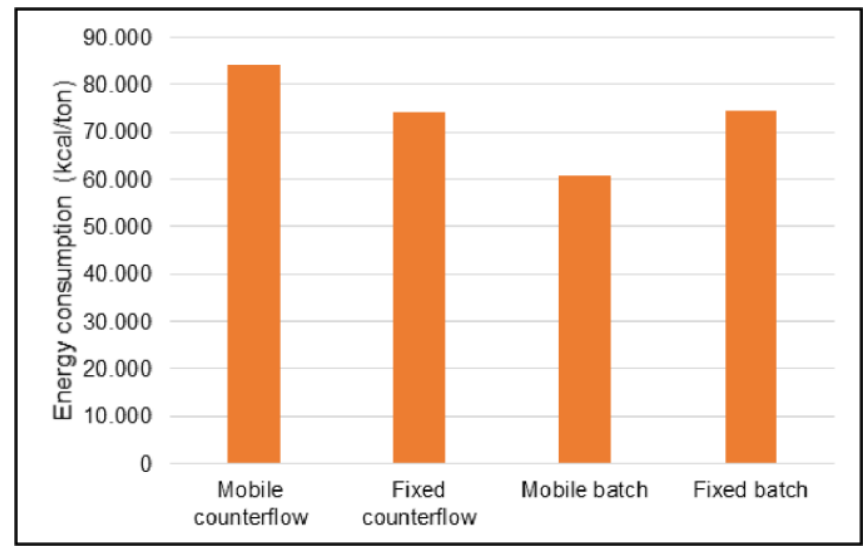




\section{Conclusion}

This study aimed to evaluate the environmental performance of different models of asphalt plants based on $\mathrm{CO}_{2 \text { eq }}$ emissions and energy consumption per ton of aggregate processed in the dryer drum. Through the $\mathrm{GHC}$ Protocol tool, $\mathrm{CO}_{2 \text { eq }}$ emissions from three different fuels were quantified: natural gas, LPG, and LPP oil. At the same time, with the aid of an Excel spreadsheet, energy consumption per ton of processed aggregate was also calculated.

It was found that the energy demand per ton processed can vary significantly between the models. In fact, regarding the fixed counterflow type plant model, there was a reduction of up to $54.3 \%$ in the energy demand between them. The model that demanded the least energy was the MB2 (Mobile Batch model 2) $(57,118.29 \mathrm{kcal} / \mathrm{t}$ ), and the highest consumption was in the FC1 model (Fixed Counterflow model 1) $(125,537.41 \mathrm{kcal} / \mathrm{t})$. The average reduction in $\mathrm{CO}_{2 \text { eq }}$ emissions using natural gas and LPG was $26.11 \%$ and $18.25 \%$ respectively, compared to LPP oil. The use of natural gas reduced $\mathrm{CO}_{2 \text { eq }}$ emissions by $9.62 \%$ when compared to the use of LPG.

Among the models evaluated, the use of LPP oil had the worst performance, which is associated with the FC1 model $\left(40.50 \mathrm{~kg} \mathrm{CO}_{2 \text { eq }} / \mathrm{t}\right)$. The models that had the lowest emissions when using natural gas were: MB2 (13.62 kg CO2eq / t), MC6 (Mobile Counterflow model 6) (13.64 kg CO 2 eq $/ \mathrm{t}$ ), FC3, and FC4 (Fixed Counterflow models 3 and 4) $\left(13.67 \mathrm{~kg} \mathrm{CO}_{2 e q} / \mathrm{t}\right)$. Thus, the use of natural gas as an energy source for heating and drying aggregates, in addition to the use of models with lower emissions, can provide structures with better environmental performance. Finally, it is believed that this study can contribute to the studies of emissions in asphalt mixing plants in Brazil.

\section{Acknowledgments}

The authors would like to thank the National Council for Scientific and Technological Development (CNPq) and the Coordination for the Improvement of 
Higher Education Personnel (CAPES) for the support with scholarships. This project is funded by the National Council for Scientific and Technological Development (CNPq).

\section{References}

ADEBA, Associação Brasileira das Empresas Distribuidoras de Asfalto. Mercado - 2020 - Evolução do Mercado [Internet]. Available from: http://www.abeda.org.br/mercado/\#mercado-evolucao

ANP - AGÊNCIA NACIONAL DO PETRÓLEO, GÁS NATURAL E BIOCOMBUSTÍVEIS [Internet]. Brasília: Ministério de Minas e Energia [cited 202015 aug]. Gás Natural. Available from: http://www.anp.gov.br/gas-natural

ALMEIDA-COSTA, A.; BENTA, A. Economic and Environmental impact study of warm mix asphalt compared to hot mix asphalt. Journal of Cleaner Production. 2016; 112:23082317.

ANDROJIĆ, I.; ALDUK, Z. D.; DIMTER, S.; RUKAVINA, T. Analysis of impacto $f$ aggregate moisture contente on energy demand during the production of hot mix asphalt (HMA). Journal of Cleaner Production. 2020; 244:1-10.

AMMANN. Usinas de Asfalto; 2020 [Internet]. Gravataí (Brasil): Ammann Group; 2020 [cited 2020 Mar 22]. Available from: https://www.ammann.com/pt-br/plants/asphaltplants

BENNINGHOVEN. Produtos Benninghoven; 2020 [Internet]. Porto Alegre (Brasil): Wirtgen Group; 2020 [cited 2020 mar 21]. Available from: https://www.wirtgengroup.com/ocs/pt-tl/benninghoven/produtos-benninghoven-96-c/

BERNUCCI, L. B.; MOTTA, L. M. G.; CERATTI, J. A. P.; SOARES, J. B. Pavimentação asfáltica: Formação básica para engenheiros. 3rd. ed. Rio de Janeiro: ABEDA, 2008.

BRASIL, Ministério do Meio Ambiente. Conselho Nacional do Meio Ambiente CONAMA. Resolução $n^{\circ}$ 491/18. Dispõe sobre padrões de qualidade do ar. Brasília (Brasil): SEMA, 2018.

BRASIL, Ministérios do Meio Ambiente [Internet]. Brasília: Efeito Estufa e Aquecimento Global [cited 2020a apr 22]. Available from: https://www.mma.gov.br/informma/item/195-efeito-estufa-e-aquecimento-global

BRASIL, Ministério da Ciência, Tecnologia, Inovação e Comunicações [Internet]. Brasília: Entenda o Efeito Estufa [cited 2020b apr 21]. Available from: 
https://www.mctic.gov.br/mctic/opencms/ciencia/SEPED/clima/Comunicacao_Nacional leee.html.

BUECHE, N.; DUMONT, A. G. Energy in warm mix asphalt. In: Proceedings of the 5th Eurasphalt \& Eurobitume Congress [Internet]; 2012 13-15 th June; Istanbul, Turkey. 2012 [cited 2020 aug 7]. Available from: https://www.h-a-d.hr/pubfile.php?id=513

CIBER. Usinas de asfalto móveis contínuas; 2020 [Internet]. Porto Alegre (Brasil): Wirtgen Group; 2020 [cited 2020 mar 21]. Available from: https://www.wirtgengroup.com/ocs/pt-br/ciber/usinas-de-asfalto-moveis-continuas-107-c/

CNT, Confederação Nacional do Transporte. Pesquisa CNT de Rodovias 2019. Brasília (Brasil):CNT, 2019. 233 p.

EAPA, European Asphalt Pavement Association [internet]. Environmental guidelines on best available techniques (BAT) for the production of asphalt pavingmixes, 2007 [cited 2020 Aug 12]. Availabre from: https://pdfs.semanticscholar.org/7701/ef8c7f55da75e9a73774b303747b876d4c20.pdf ?_ga=2.54311464.1250237106.1597181299-1594946764.1581605083

Fundação Getúlio Vargas [Internet]. Rio de Janeiro: Programa brasileiro GHC Protocol, 2008 - Ferramenta de cálculo [cited 2020 Mar 05]. Available from: https://www.ghgprotocolbrasil.com.br/

HUANG, Y.; BIRD, R.; HEIDRICH, O. Development of a life cycle assessment tool for construction and maintenance of asphalt pavements. Journal Of Cleaner Production. 2009; 17:283-296.

INDOT, Indiana Department of Transportation. Certified hot mix asphalt technician manual. State of Indiana (USA): Department of Transportation, 2016. 636p.

KRISTJÁNSDÓTTIR, Ó.; MUENCH, S. T.; MICHAEL, L.; BURKE, G. Assessing Potential for Warm-Mix Asphalt Technology Adoption. Transportation Research Record, 2007; 2040(1):91-99.

MARINI. Produtos; 2020 [Internet]. Cachoeirinha (Brasil): Fayat Group; 2020 [cited 2020 Mar 19]. Available from: http://marinilatinamerica.com.br/products/.

MERIGHI, C. F.; SUZUKI, C. Y. Estudo do comportamento do revestimento de pavimento utilizando mistura asfáltica morna com adição de borracha moída de pneu na SPA248/055. Transportes. 2017; 25(4):136-146.

MILLET, D.; BISTAGNINO, L.; LANZAVECCHIA, C.; CAMOUS, R.; POLDMA, T. Does the potential of the use of LCA match the design team needs? Journal Of Cleaner Production. 2007; 15:335-346. 
MUENCH S T. Rodway Construction Sustainability Impacts: Review of Life-Cycle Assessments. Transportation Research Record, 2151(1), 36-45.

NAPA, National Asphalt Pavement Association. The Environmental Impact of Asphalt Plants SR 206 2014-05. Greenbelt, MD (USA), 2014. 3p.

NASA - National Aeronautics and Space Administration [Internet]. Washignton: The effects of climate change (USA) [cited 2020a aug 15]. Available from: https://climate.nasa.gov/effects/

NASA - National Aeronautics and Space Administration [Internet]. Washignton: The Causes of Climate Change (USA) [cited 2020b apr 28]. Available from: https://climate.nasa.gov/causes/

PARANHOS, R. S.; PETTER, C. O. Multivariate data analysis applied in Hot-Mix asphalt plants. Resources, Conversvation and Recycling. 2013; 73:1-10.

PEINADO, D.; VEGA, M.; GARCÍA-HERNANDO, N.; MARUGÁN-CRUZ, C. Energy and exergy analysis in an asphalt plant's rotary dryer. Applied Thermal Engineering. 2011; 31(67):1039-1049.

PENG, B.; CAI, C.; YIN, G.; LI, W.; ZHAN, Y. Evaluation system for CO2 emission of hot asphalt mixture. Journal of Traffic and Transportation Engineering. 2015;2(2):116-124.

PETERSON, B. Drum vs. batch plant: learn the differences that will make your asphalt mix just right [Internet]. Westwood (MA): Chase Corporation; 2018 May 10 [cited 2020 may 21]. Available from: https://blog.chasecorp.com/bridge-and-highway/drum-vs.batch-plant-learn-the-differences-that-will-make-your-asphalt-additive-product-justright.

PETROBRAS. Óleo combustível: Informações técnicas [Internet]. Rio de Janeiro (Brasil) V. 1.4 [cited 2020a aug 15]. Available from: http://sites.petrobras.com.br/minisite/assistenciatecnica/public/downloads/manualtecnico-oleo-combustivel-assistencia-tecnica-petrobras.pdf

PETROBRAS. Gás Liquefeito de petróleo: Informações técnicas [Internet]. Rio de Janeiro (Brasil) [cited 2020 aug 15]. Available from: http://sites.petrobras.com.br/minisite/assistenciatecnica/public/downloads/manualtecnico-gas-liquefeito-petrobras-assistencia-tecnica-petrobras.pdf

PEURIFOY, R. L.; SCHEXNAYDER, C. J.; SHAPIRA, A.; SCHMITT, R. L. Planejamento, equipamentos e métodos para a construção civil. 8. ed. Porto Alegre: Amgh Editora Ltda, 2015. p. 466-512. 
RUBIO, M. D. L.; MORENO, F.; MARTÍNEZ-ECHEVARRÍA, M. J.; MARTÍNEZ, G.; VÁZQUEZ, J. $M$. Comparative analysis of emissions from the manufacture and use of hot and halfwarm mix asphalt. Journal of Cleaner Production. 2013; 41:1-6.

USEPA, United State Environmental Protection Agency. AP - 42: Compilation of air emissions factors. Chapter 11.1: Hot mix asphalt plants emission assessment report. Research Triangle Park, NC (USA), 2004. 63p.

USEPA. United State Environmental Protection Agency [Internet]. Washigton: Overview of Greenhouse Gases [cited 2020 mar 29]. Available from: https://www.epa.gov/ghgemissions/overview-greenhouse-gases.

VENTURA, A.; MONERÓN, P.; JULLIEN, A.; TAMAGNY, P.; OLARD, F.; ZAVAN, D. Environmental comparison at industrial scale of hot and halfwarm mix asphalt manufacturing processes. In: Transportation Research Board 88th Annual Meeting [Internet]; 2009 January 11-15; Washington. p. 12.

WANG, T.; LEE, I. S.; KENDALL, A.; HARVEY, J.; LEE, E. B.; KIM, C. Life cycle energy consumption and GHG emission from pavement rehabilitation with different rolling resistance. Journal Of Cleaner Production. 2012; 33:86-96.

WHITE, P.; GOLDEN, J. S.; BILIGIRI, K. P.; KALOUSH, K. Modeling climate change impacts of pavement production and construction. Resources, Conservation and Racycling. 2010; 54:776-782.

$\mathrm{XU}, \mathrm{B}$;; LIN, B. Can expanding natural gas consumption reduce China's CO2 emissions?. Energy Economics. 2019; 81:393-407.

ZANETTI, M. C.; SANTAGATA, E.; FIORE, S.; RUFFINO, B.; DALMAZZO, D.; LANOTTE, M. Evolution of potential gaseous emissions of asphalt rubber bituminous mixtures. Proposal of new laboratory test procedure. Construction and Building Materials. 2016; 113:870-879. 